\title{
Preliminary design of potential storage facility for low and intermediate level radioactive waste
}

The Mining-Geology-Petroleum Engineering Bulletin UDC: 622.8

DOI: $10.17794 / \operatorname{rgn} .2018 .2 .3$

Preliminary communication

\author{
Tanja Mališ̌́; Anni Milling²; Antonia Jaguljnjak-Lazarević ${ }^{3}$ \\ University of Zagreb, Faculty of Mining, Geology and Petroleum Engineering, Department of Mining and Geotechnical Engineering, \\ Pierottijeva 6, HR-10000 Zagreb, Croatia \\ ${ }^{1}$ Postdoctoral Researcher, PhD; ${ }^{2}$ graduated student, mag.geol.; ${ }^{3}$ Assistant Professor, PhD
}

\begin{abstract}
An issue concerning the management of radioactive waste (RAW) in the Republic of Croatia continuously rises due to the lack of systematic solutions. In this paper, emphasis is being placed on the storage of RAW, as one of the important phases of RAW management. The current RAW storage facilities are not sufficient and there is a need for a new facility for low and intermediate level radioactive waste (LILW), since such waste accounts for the largest part of RAW. For this reason, a preliminary estimate for a one-storey structure was carried out, a potential storage facility of LILW that would be constructed at the location of Čerkezovac, Trgovska Gora, in the Republic of Croatia, as the currently most prominent location for the realization of the RAW storage facility. The geological characteristics of the site were analysed and, in accordance with the relevant regulations, a static design of the facility was made in the ETABS and SAFE program packages. The construction is a typical reinforced concrete structure, rectangular in plan (10.0 x $30.0 \mathrm{~m}$ ) with a height of 5.9 $\mathrm{m}$. The selected location meets the given parameters of geological characteristics, while the construction meets the given load and serviceability conditions defined by Eurocode (ultimate limit state and serviceability limit state). However, a more detailed analysis would be necessary if the decision to construct such a storage facility would be made.
\end{abstract}

Keywords

storage facility, low and intermediate radioactive waste, preliminary design of storage facility, geological features, RC structure

\section{Introduction}

Radioactive waste (RAW) is the product of technology with processes using radioactivity or ionising radiation. In the Republic of Croatia, RAW comes from a number of activities, primarily from medicine, energetics, industry and scientific research. According to the list of hazardous sources of ionising radiation published by the State Office for Radiological and Nuclear Safety (as a state body coordinating all the activities dealing with the safety of sources of ionising radiation in the Republic of Croatia), there are 38 currently registered locations with activities using radioactive sources, using a total of 133 sources in all four categories (State Office for Radiological and Nuclear Safety, 2017). Although this is significantly less compared to the 510 institutions and organizations registered for authorised use of ionising radiation sources in 1992 (Subašić et al., 1992), the problems of RAW management in our country become more and more important due to the lack of systematic solutions. The emphasis in this paper is being placed on the RAW storage problem, as one of the crucial phases

Corresponding author: Tanja Mališ

tanja.malis@rgn.hr of RAW management, for which we will inevitably have to find a solution in the near future.

Presently, there are two temporary storage facilities for low and intermediate level radioactive waste (LILW) in the Republic of Croatia, located within the Institute for Medical Research and Occupational Medicine and the Ruđer Bošković Institute. They are closed for accepting new waste. In addition, only institutional RAW was disposed of, that is the waste generated by the use of radioactive sources and materials in medical diagnostics and treatment, the removal of radioactive smoke detectors and lightning conductors, and in research using sources of ionising radiation. Stemming from the ratified international agreement (Croatian Parliament, 2002, article 10 paragraph 7), the Republic of Croatia is obligated to permanently manage $50 \%$ of its radioactive waste from the Krško nuclear power plant (Krško NPP), created during the power plant's operation and the subsequent decommissioning of the facility itself after its shutdown (Veinović, 2016). According to the Strategic study for the National Programme for the implementation of the Strategy for the management of radioactive waste, disused sources and spent nuclear fuel (EKONERG - Energy and Environmental Protection Institute, 2016), in the specific situation in the Republic of 
Croatia, the first planned phase of the management of radioactive waste is the storage of institutional RAW, used sources and LLIW from the Krško NPP, including the decommissioning LLIW (from 2023 to 2060). The solution to the problem of the institutional RAW disposal, used sources and LLIW from the Krško NPP is planned for the future (from 2060 to 2065).

It appears that the current storage conditions of LLIW are insufficient and there is a need for a new storage facility. Generally, radioactive waste must be located in a depot or storage facility whose barriers prevent any contact with the biosphere. Ideally, all radioactive waste would be disposed of deep underground, but such buildings would be economically unprofitable to build and maintain. From the aspect of design, the mitigating circumstance is that LLIW radioactivity will not remain significantly higher for more than a few centuries, because it was not particularly high at all and it does not contain large concentrations of long-lasting radionuclides. Since its half-life is less than 30 years, there is no need to deploy it hundreds of meters deep underground, in the stable and impermeable geological layers and structures. Hence, LLIW depots and storage facilities are built on the surface itself or in the soil at a depth of only a few meters (Levanat and Lokner, 2000). The storage facilities for LLIW are usually solid, one storey or partially buried buildings that are located in a suitable location where no floods, large rainfall or groundwater drainages, significant erosive, tectonic and seismic processes are expected. Also, the expected bedrock permeability is low (Milling, 2017).

\section{Designing tasks}

Landfills, as well as temporary landfills or hazardous waste storage facilities are considered to be of state significance for the Republic of Croatia (Government of the Republic of Croatia, 2014). Also, they are among the most complex buildings, that is buildings of the first group according to the Building Act (Croatian Parliament, 2013). During the construction of such buildings it is necessary to obtain all relevant permits specified by the same law, i.e. location, building and use permits, that is develop the preliminary design, main design and the detailed design. An environmental impact assessment is required to obtain a permit for the construction of a storage facility.

The relevant international treaty that should be taken into consideration in the design is the Act on the Ratification of the Joint Convention on the Safety of Spent Fuel Management and on the Safety of Radioactive Waste Management (Croatian Parliament, 1999). Furthermore, at the European level, the EU's main document governing the implementation of protection against ionizing radiation is the Council Directive 2013/59 / EURATOM from December $5^{\text {th }}, 2013$ on basic safety standards for protection against the dangers arising from exposure to ionizing radiation, which must be incorporated in the national regulations of the EU Member States until February $6^{\text {th }}, 2018$. In the Republic of Croatia, the Act on Radiological and Nuclear Safety (Croatian Parliament, 2013) is in force, containing provisions in accordance with this Directive (EKONERG - Energy and Environmental Protection Institute, 2016).

In addition to the relevant national regulations, that are the above-mentioned Building Act, the Act on Radiological and Nuclear Safety, by-laws issued under these Acts and other national regulations, during the design of the LLIW storage facility it would be advisable to comply with the safety standards issued by the International Atomic Energy Agency (IAEA), especially since the Republic of Croatia is a member. Particularly interesting is the safety standard WS-G-6.1, "Storage of Radioactive Waste" from 2006, whose general guideline is that storage facilities should be designed in such a way that waste can be received, handled, stored and retrieved without undue occupational and public radiation exposure or environmental impact (IAEA, 2006).

\section{Choosing the location}

Choosing an adequate location for the storage facility structure is immensely difficult. The RAW management program on the territory of the Republic of Croatia dates back to 1979 to the Krško NPP construction period, and the separate Croatian program for selecting the location for the LLIW landfill or storage facility started in 1988 . Ten criteria have been used: flood safety, seismotectonics, neotectonics, lithological and geomorphological characteristics, hydrogeology, population density, special purpose areas, mining and mineral exploitation, protection of the natural heritage and protection of the cultural heritage. An additional assessment of the mentioned criteria resulted in the establishment of comparative criteria divided into six groups, that is RAW transport, meteorology and hydrology, geology and seismology, demography, purpose and use of space and environmental protection (Schaller and Lokner, 1998). The most prominent choice of location to date is the Trgovska Gora, and so the proposal of an appropriate warehouse at that location was discussed in this paper.

The considered location is the military location of Čerkezovac, located in the municipality of Dvor, which is a part of the Sisak-Moslavina County. The old military barracks are located on the southern slopes of Trgovska Gora at an altitude of about $300 \mathrm{~m}$ above sea level and occupying an area of $0.6 \mathrm{~km} 2$. The town of Dvor na Uni is about $6 \mathrm{~km}$ north-east of the barracks. The state border with the neighbouring Bosnia and Herzegovina that coincides with the river Una is about $3 \mathrm{~km}$ east or $4 \mathrm{~km}$ south of the barracks (State Office for Radiological and Nuclear Safety, 2015).

If we consider the geological characteristics of the proposed location, the Črkezovac site represents the 
highest point of 319.4 meters above sea level of the eastern part of Trgovska Gora, making it difficult for the river to flood the area so the location meets the hydrological aspects of flood safety. Being outside the reach of the mountain streams there is a lesser possibility of development and risk of erosion processes (State Office for Radiological and Nuclear Safety, 2015), which satisfies the defined criteria (Government of the Republic of Croatia, 1992).

Furthermore, the location basically meets both relevant hydrogeological criteria (Government of the Republic of Croatia, 1992): there are no natural health sources on it as well as no significant sources of drinking water and it is not within a spread area of significant aquifers (State Office for Radiological and Nuclear Safety, 2015). The area of the military facility of Črkezovac is covered with carbon paleozoic deposits where no detailed research has been carried out. Due to the high coverage of the terrain, the rare outcrops geologists have found were weathered coarse grained sandstones. On rare occasions, siltites and fine grained sandstones in alternation, and the presence of fracture systems pointing to tectonic disturbance of deposits have been found. Regardless of the inability to estimate lithological units solely on the basis of geological maps, the limits of the distribution of the clastic deposits of Pal-
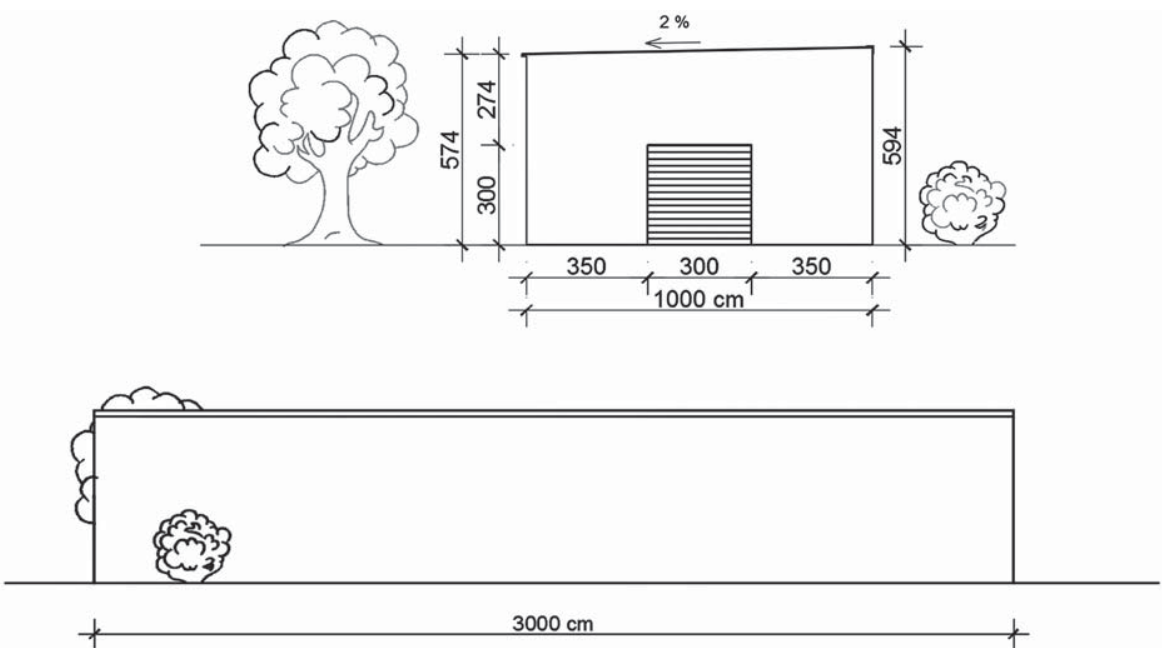

Figure 1: Storage facility views: entrance and side facade
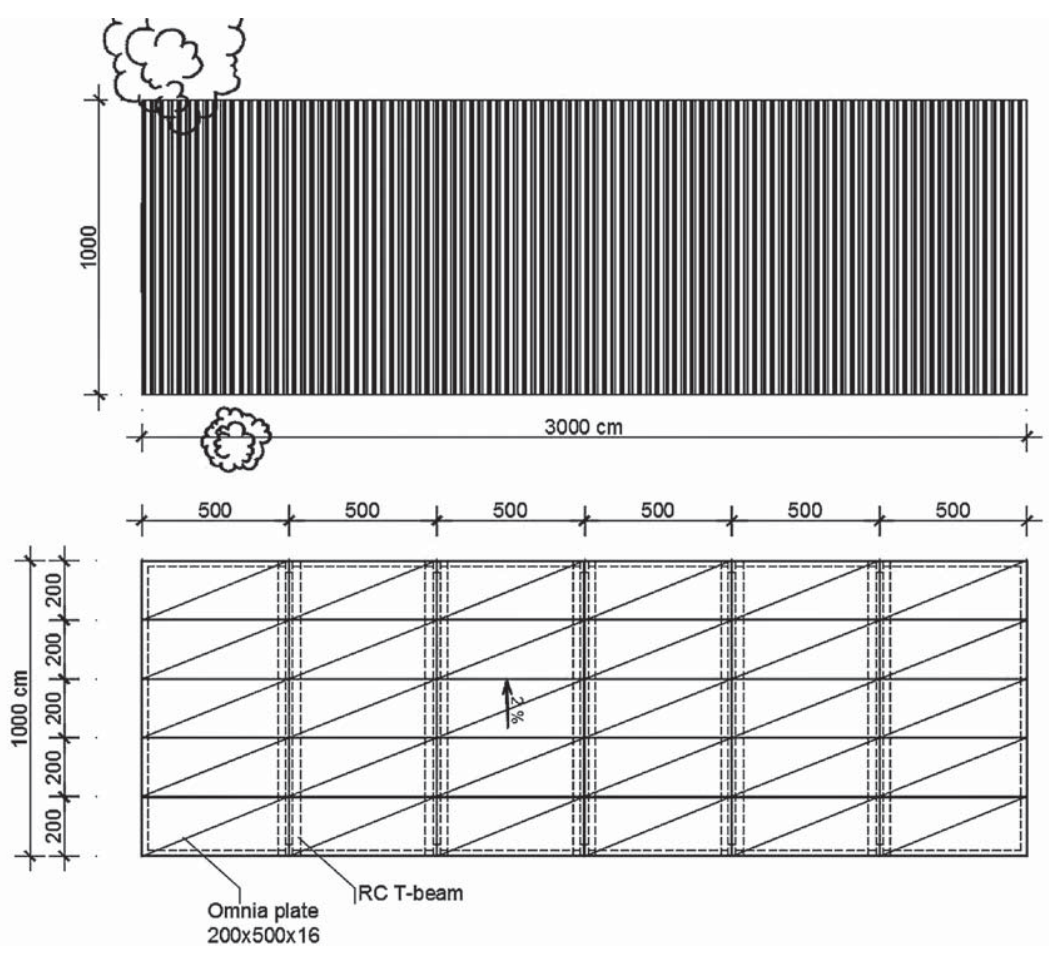

Figure 2: Top view of corrugated sheet and the position of the roof elements ( $\mathrm{T}$ section beams and Omnia plates) 


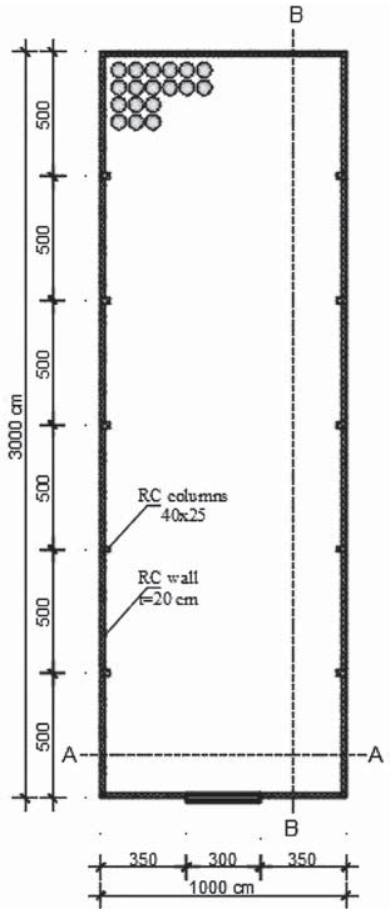

Figure 3: Section of the storage facility through the walls and columns aeozoic on the maps of apparent resistances at all depths indicate a considerable deposit thickness (up to $2000 \mathrm{~m}$ ) which is a favourable factor for the possible realization of the project at Čerkezovac (Milling, 2017).

The volcanogenic - sedimentary formation of Trgovska Gora is located in a $3 \mathrm{~km}$ wide belt that is prone to strong erosion and intensive gullying, which is why there is a relatively high possibility of landslide formation. However, the top plateau on which the military object is located, assuming it is located on the shale deposits, is a favourable terrain for the RAW storage facility. Vegetation cover consisting of a deciduous forest also greatly favours the stability of the slope (Milling, 2017).

In the observed period from 1323 to 2013, 892 earthquakes were recorded at the considered location. Most of the earthquakes were of intensities up to $\mathrm{VI}{ }^{\circ}$ on the MCS scale, while three previously recorded earthquakes had higher values. The most important of the three most intense earthquakes is the earliest one that occurred in Banja Luka in 1969, with an intensity of $\mathrm{VII}^{\circ}$ by the MCS scale (Milling, 2017). The distance to Cerkezovac from the epicentre in Banja Luka is $73 \mathrm{~km}$. From the point of view of seismotectonic and seismic location features, the location may be considered to be suitable
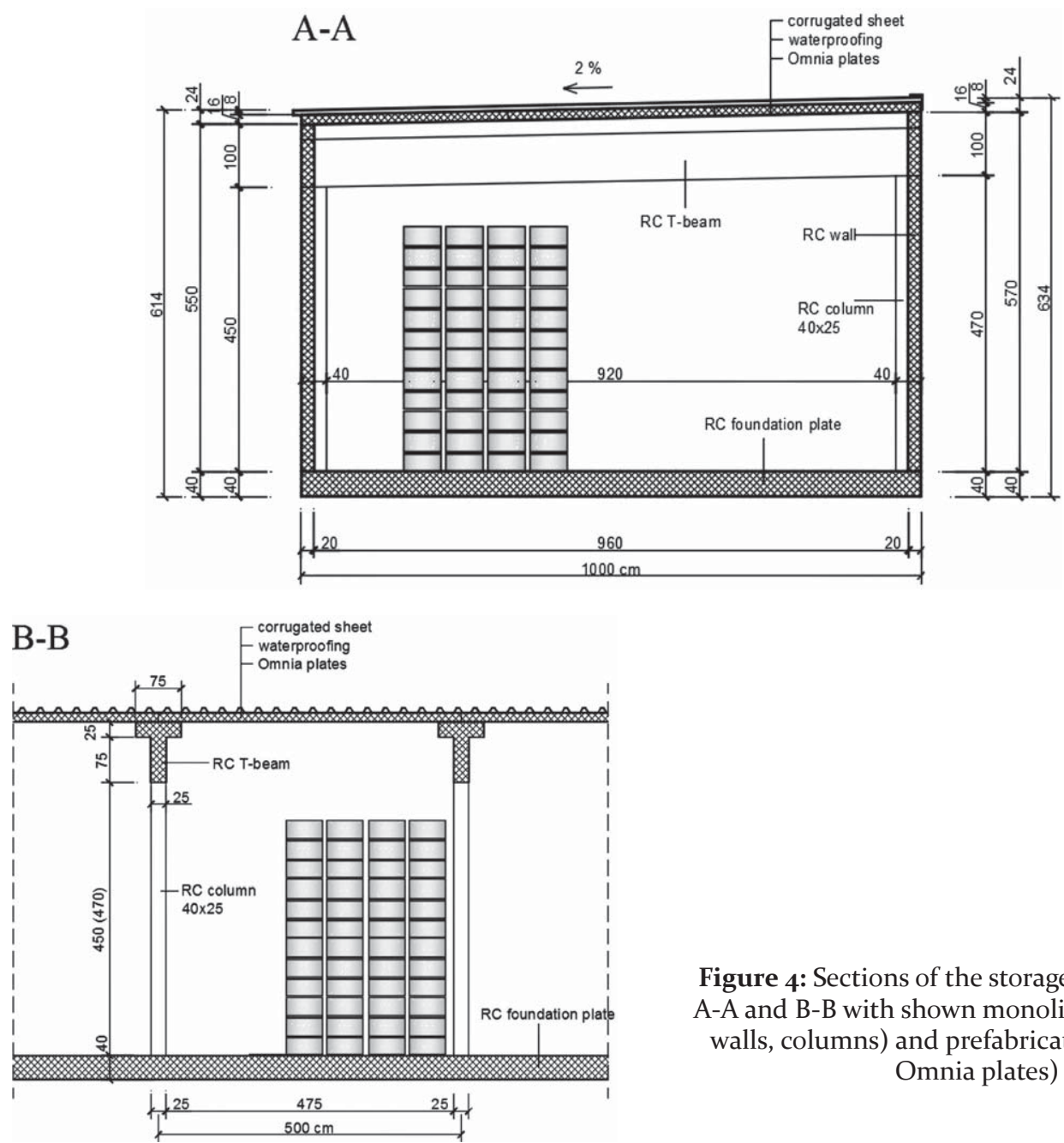

Figure 4: Sections of the storage facility in the profiles A-A and B-B with shown monolithic (foundation plate, walls, columns) and prefabricated (T section beams, Omnia plates) parts 
for the intended purpose as it basically meets all the relevant criteria (Government of the Republic of Croatia, 1992): it does not show a tendency for geodynamic phenomena or karst phenomena that could endanger rock mass stability or other phenomena that could change the degree of the surface slope beyond the established technological conditions, it is not in the zone of nominated active faults and the maximum expected intensity of an earthquake is not greater than $9^{\circ}$ MCS (State Office for Radiological and Nuclear Safety, 2015).

\section{Preliminary design of the proposed structure}

According to the available sources (State Office for Radiological and Nuclear Safety, 2015), the plan is to convert existing military storage facilities at the Čerkezovac location to a RAW storage facility with the necessary infrastructure, that is to try to use the already existing infrastructure facility as a future RAW disposal centre, if that would be feasible according to the technological and security criteria. In this manner, the already existing facilities would be utilized at a location where no public purpose is planned. However, since a firm decision about the location has not yet been adopted at the national level, in this paper, a preliminary static design in the ETABS and SAFE packages for the proposed new

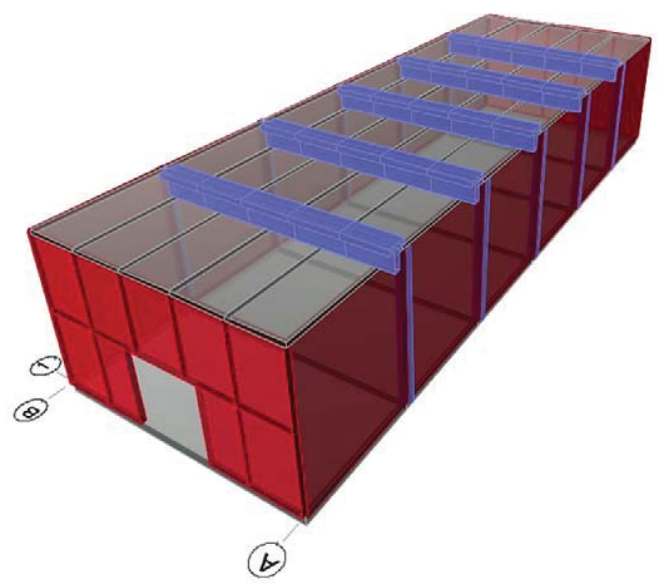

Figure 5: Structural (numerical) model: frames (blue), walls (red) and foundation plate (grey) building (surface storage facility) has been made. In the case of a decision to build an actual new building (storage facility), a more comprehensive, elaborate static design and a storage facility project should be carried out in accordance with all the mentioned relevant regulations.

\subsection{Technical description}

The proposed structure is a predominantly monolithic rectangular, typical reinforced one storey concrete (RC) building with plan dimensions of $10.0 \mathrm{~m}$ x $30.0 \mathrm{~m}$ and a height of $5.9 \mathrm{~m}$, with prefabricated parts: T-section beams and Omnia plates. It is intended for the disposal of low and intermediate level radioactive waste (Milling, 2017). The main load-bearing structure system consists of reinforced concrete walls and frames. Elements of the frame are rectangular columns and T-section beams that are freely supported by the columns. The roof structure is made from $\mathrm{RC}$ prefabricated, $16 \mathrm{~cm}$ thick Omnia plates with dimensions of $2 \times 5 \mathrm{~m}$. The vertical load is transferred through the Omnia plates to the beams, and then it is mostly transferred to the columns and in smaller part to the walls. The storage facility is founded on a reinforced, $40 \mathrm{~cm}$ thick concrete base plate. The roof is impassable. The structure is regular in both the plan view and in height. The dominant horizontal load (earthquake) was taken over by RC walls and RC frames.

The calculation and the design of structural elements have been done for the dead, superimposed dead, live load, snow load and earthquake load. Wind load was not taken into consideration. All elements of the modelled structure are constructed from C 30/37 class concrete and B500 reinforcement bars. The protective layer of the base plate is $5.0 \mathrm{~cm}$, and of the other RC elements 4.0 $\mathrm{cm}$. The entire structure design was done in ETABS and SAFE software packages according to the applicable Croatian regulations including the recognized rules of the profession. The software package ETABS is used for the spatial model of the structure, while the software package SAFE is applied to the design of plates as independent plane (XY) sub models of the structure. The software package automatically includes the self-weight of the structure into calculation. The snow load was calculated for the location area. The relevant horizontal load

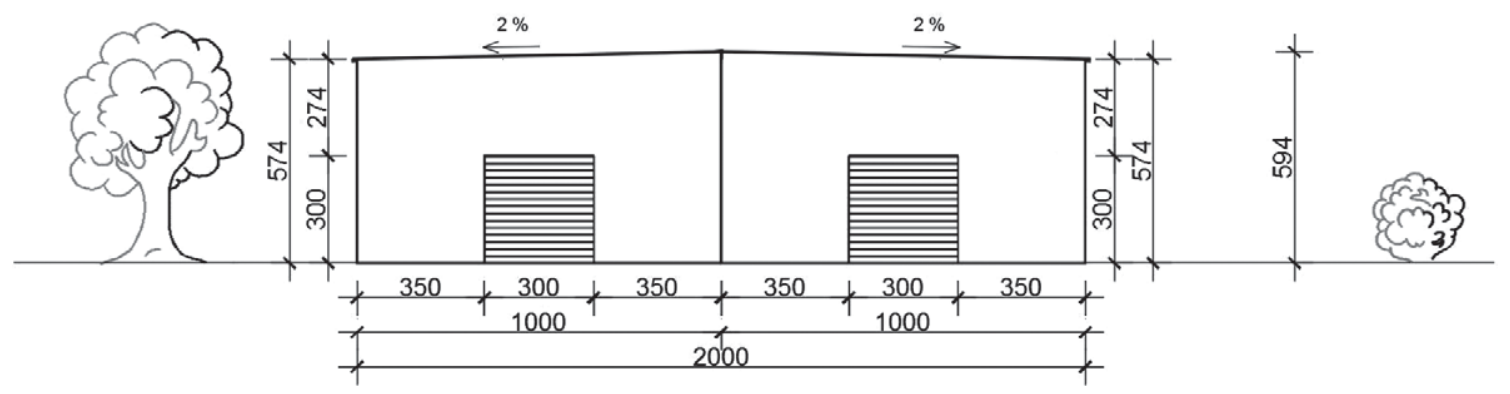

Figure 6: Structure with two modules connected in a longitudinal horizontal direction 
is earthquake (not wind). The structure is in the region of horizontal peak ground acceleration $a_{g}=0.102 \mathrm{~m} / \mathrm{s}^{2}$, soil category $\mathrm{B}$ and the behaviour factor 1.5 . A response spectrum was formed according to the applicable regulations. The stiffness of the foundation soil was included into the design through the Winkler model of elastic springs that influence the foundation slab.

The sketch of the storage facility was done in AutoCAD. The views are shown in Figure 1, the top view and the position of the roof panels in Figure 2, the section of the storage facility through the columns and walls in Figure 3. Figure 4 shows the sections of the storage facility in profile A-A and profile B-B. Figure 5 shows the model of the structure in the computer program ETABS 2014. In case of urgency for a larger storage facility, this design could be used as a design for one module, and the modules could be connected in a longitudinal horizontal direction. The example of the structure with two modules is shown in Figure 6.

\subsection{Load analysis}

\subsubsection{Load}

In addition to its own weight as the basic constant load that the program package automatically takes into account for the given dimensions and material $\left(\gamma_{A B}=25 \mathrm{kN} / \mathrm{m}^{3}\right)$, the addition of a constant load from the immovable equipment was taken into account in the calculation. The barrels in which the radioactive waste is stored, with a maximum value of the total added load with which the calculation was done and equals $G=80.00 \mathrm{kN} / \mathrm{m}^{2}$. The live load (a loaded forklift) was estimated at: $Q=10.00 \mathrm{kN} / \mathrm{m}^{2}$.

Table 1: Load combinations for design

\begin{tabular}{|c|c|c|}
\hline Name & Load Case & Scale Factor \\
\hline \multirow{3}{*}{$\begin{array}{l}\text { Ultimate limit state } \\
\text { (without earthquake), ULS }\end{array}$} & $\mathrm{G}_{\mathrm{SW}}$ & 1.35 \\
\hline & $\mathrm{G}_{\mathrm{SD}}$ & 1.35 \\
\hline & Q & 1.5 \\
\hline \multirow{4}{*}{$\begin{array}{l}\text { Ultimate limit state } \\
\text { (with earthquake), ULS }\end{array}$} & $\mathrm{G}_{\mathrm{SW}}$ & 1 \\
\hline & $\mathrm{G}_{\mathrm{SD}}$ & 1 \\
\hline & Q & 0.3 \\
\hline & $\mathrm{A}_{\mathrm{E}, 475}$ & 1 \\
\hline \multirow{3}{*}{$\begin{array}{l}\text { Ultimate limit state } \\
\text { (favourable self-weight), } \\
\text { ULS }\end{array}$} & $\mathrm{G}_{\mathrm{SW}}$ & 0.9 \\
\hline & $\mathrm{G}_{\mathrm{SD}}$ & 0.9 \\
\hline & $A_{E, 475}$ & 1 \\
\hline \multirow{3}{*}{$\begin{array}{l}\text { Serviceability limit state } \\
\text { (without earthquake), SLS }\end{array}$} & $\mathrm{G}_{\mathrm{SW}}$ & 1 \\
\hline & $\mathrm{G}_{\mathrm{SD}}$ & 1 \\
\hline & $\mathrm{Q}$ & 1 \\
\hline \multirow{4}{*}{$\begin{array}{l}\text { Serviceability limit state } \\
\text { (with earthquake), SLS }\end{array}$} & $\mathrm{G}_{\mathrm{SW}}$ & 1 \\
\hline & $\mathrm{G}_{\mathrm{SD}}$ & 1 \\
\hline & Q & 0.3 \\
\hline & $\mathrm{A}_{\mathrm{E}, 475}$ & 1 \\
\hline
\end{tabular}

For the location of the storage facility, in accordance with the national addition to the Eurocode 1, a characteristic value of the snow load on the ground was read as $s_{k}=1.50 \mathrm{kN} / \mathrm{m}^{2}$ which was taken whole as a part of the total moving load.

Since the Eurocode 8 recommends the calculation of the earthquake load for $T_{p}=475$ year return period, the chosen ground acceleration is $a_{g}=0.102 \mathrm{~m} / \mathrm{s}^{2}$. The seismic calculation was made with a spectral analysis on the
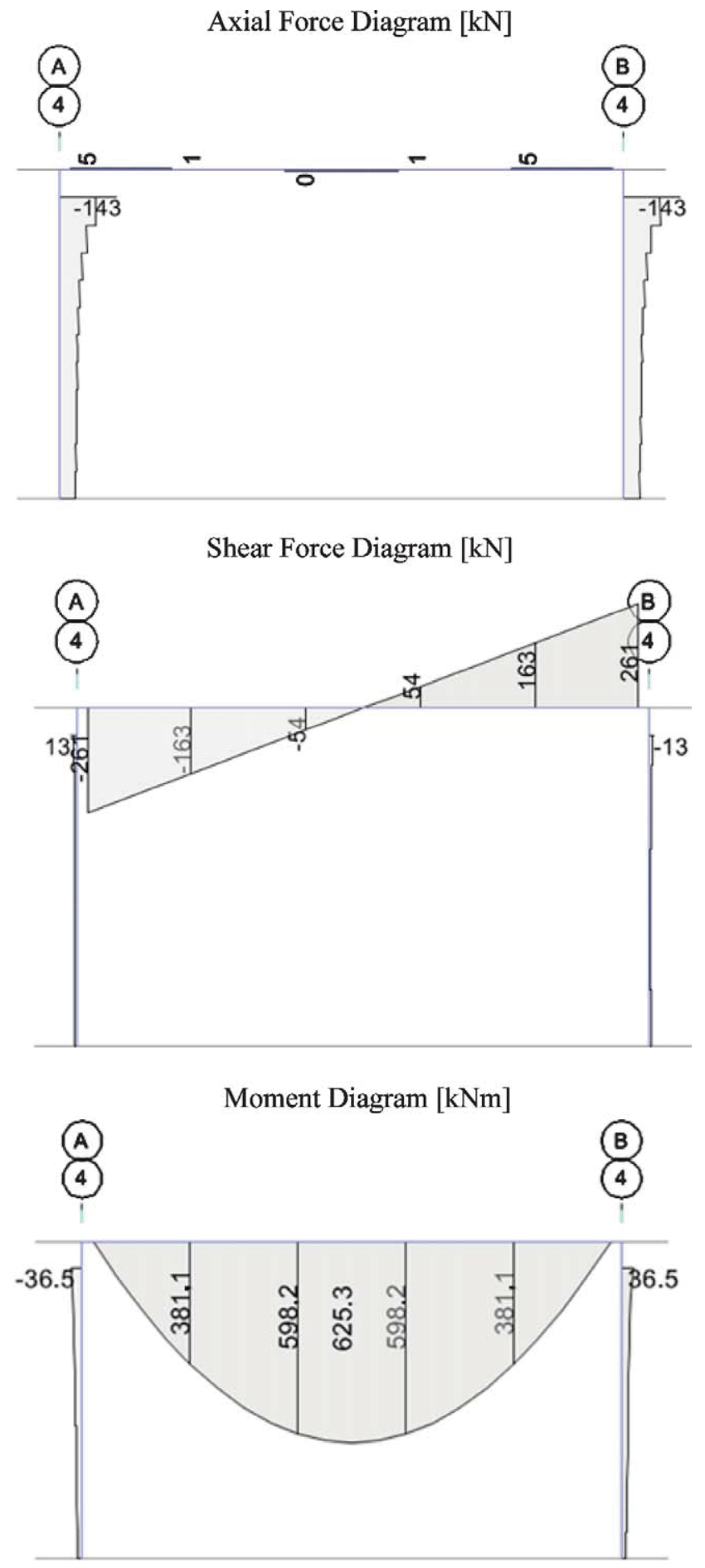

Figure 7: Diagrams of internal forces: axial forces, shear forces, moments around the major axis for ULS 
basis of the response spectrum for the exact location of the storage facility. The earthquake calculation was made for the B category of soil. In the calculation, the behaviour factor $q=1.5$ is used to model (assumed) very small (so call limited) non-elastic behaviour of the structure.

\subsubsection{Load combinations}

The following load cases are defined in the software tools: Dead (self-weight, $G_{S W}$ ), Superimposed Dead (fixed equipment, $G_{S D}$ ), Live (imposed load and snow, $Q)$, Earthquake Load for $T_{p}=475$ years $\left(A_{E, 475}\right)$ and for $T_{p}=95$ years $\left(A_{E, 95}\right)$. According to Eurocode, the situations of the extreme limit states are explicitly defined as: ultimate limit state and serviceability limit state, whereby the load combinations are multiplied by the predefined parameters defined by Eurocode, as shown in Table 1.

\subsubsection{Internal force diagrams}

Figure 7 shows the relevant axial force diagrams, shear force diagrams and frame bending moments for the ultimate limit state ULS.

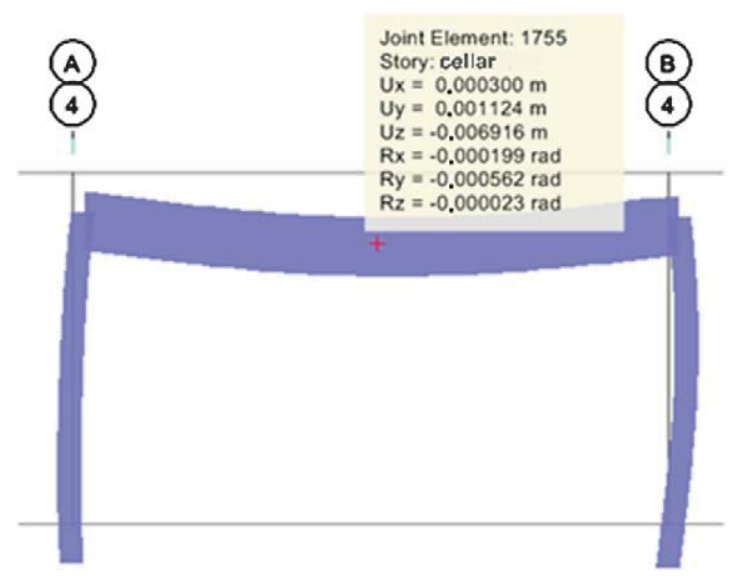

Figure 8: Displacements during the earthquake load for SLSE

\subsubsection{Displacements during the seismic load}

Figure 8 shows the displacements in the characteristic cross-section for the earthquake activity for a return period of $\mathrm{Tp}=95$ years, which meets the load conditions. Restricting relative displacement of adjacent floor plates for a serviceability limit state in earthquakes in a $95-$ year return period: $d_{k a t} \leq 0.005 \cdot h=2.50 \mathrm{~cm}$.

\subsection{Design of the structure}

The required longitudinal reinforcement, for the upper part of the beam and the beam itself, for a critical combination of loads in the compression (the upper part of the beam) is $6.9 \mathrm{~cm}^{2}$ while in the tension zone it is $15.5 \mathrm{~cm}^{2}$. The largest required surfaces of the transverse reinforcement of the beam (stirrup) are needed at the ends of the beam and they are $6.5 \mathrm{~cm}^{2} / \mathrm{m}$. For the crosssection of a column $d=40 \mathrm{~cm}$, the required longitudinal reinforcement is $25 \mathrm{~cm}^{2}$, and the required transverse reinforcement is $2.1 \mathrm{~cm}^{2} / \mathrm{m}$.

The chosen reinforcement in the walls is: $\not 10 / 15 \mathrm{~cm}$ (Q524) - on both sides and $4 \varnothing 14$ - bars at the edges. The required cross and longitudinal reinforcements in the spandrel above the door: $4 \phi 20$ - bars at the lower edge and $\phi 10 / 15 \mathrm{~cm}(Q 524)$ - on both sides.

\subsection{Base plate}

The base plate design was done in the software package SAFE. The coefficient of the base is $k=20000 \mathrm{kN} / \mathrm{m}^{2}$. The maximum bending moment in the base plate is $62.7 \mathrm{kNm} / \mathrm{m}$ (see Figure 9) and it is symmetrical on both sides. The minimum values of moments are at the edges of the plate, except at the places of columns and the entrance to the storage facility.

The largest deflections are at the edges of the plate, which means that the columns must not end at the edges of the base plate in order to prevent the collapse of the same, what should be considered in the detailed analy-

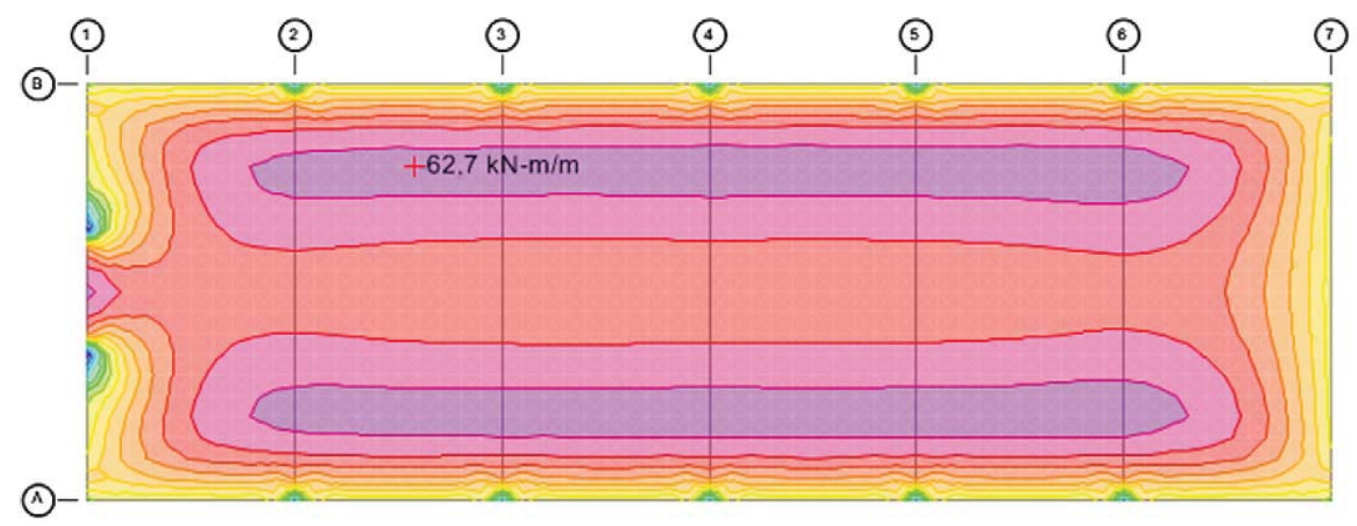

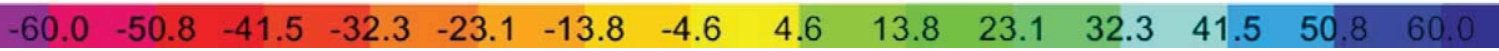

Figure 9: Bending moment in the base plate for the vertical load for ULS $[\mathrm{kNm} / \mathrm{m}]$ 


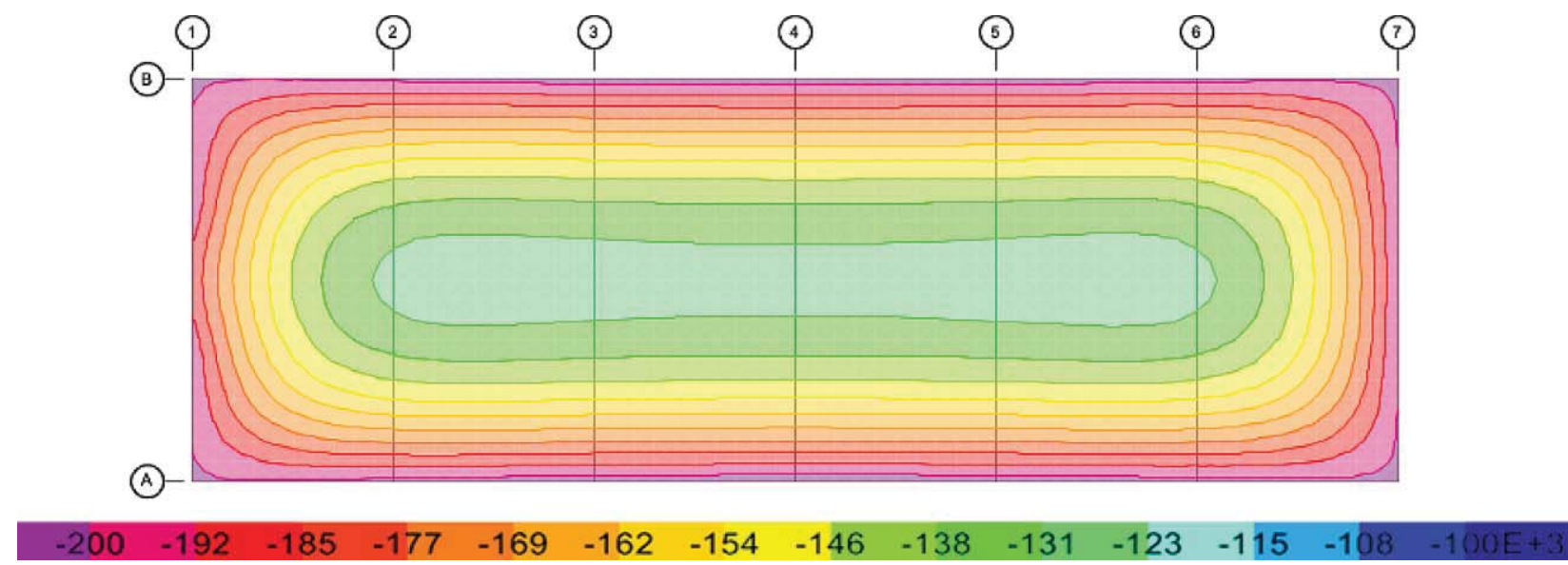

Figure 10: The soil pressures of the base plate for the vertical load for ULS $\left[\mathrm{kN} / \mathrm{m}^{2}\right]$

sis. The maximum foundation settlement is $7 \mathrm{~mm}$ for the maximum vertical load.

The maximum soil pressures of the base plate for the vertical load reach up to $200 \mathrm{kN} / \mathrm{m}^{2}$ (see Figure 10), thus satisfying the soil failure criterion if it is assumed that the soil bearing is $300 \mathrm{kN} / \mathrm{m}^{2}$.

The edges of the plate need to be reinforced with and also reinforced with U-forks $\phi 8 / 15 \mathrm{~cm}$. The reinforcement of the walls and the columns needs to be properly anchored and bent into the base plate. The plate needs to be reinforced on the both sides with a mesh $Q=785(\phi 10 / 10 \mathrm{~cm})$.

\subsection{Roof plate}

The Omnia plate is a $16 \mathrm{~cm}$ thick, prefabricated plate with dimensions of $5.0 \times 2.0 \mathrm{~m}$. It is resting on both sides on the frame beams or the outer walls. The maximum moment is the result of its own weight, additional permanent and movable loads and amounts to $M_{\max }=26 \mathrm{kNm} / \mathrm{m}$. The dimensions are determined by the manufacturer.

\section{Conclusion}

A delay in the disposal of spent fuel and RAW that requires safe and efficient management presents a key problem in sustainable RAW management, so an adequate solution is needed. The RAW storage facilities are constructed at a smaller or greater depth in solid ground or on the surface itself. The design of the storage facility is carried out in order to prevent the penetration of unacceptable quantities or concentrations of radionuclides from waste into the environment, which could adversely affect human health. LLIW is characterized by the fact that its half-life is less than 30 years so there is no need for storage underground.

The considered location is the military location of Čerkezovac, located in the municipality of Dvor, which is a part of the Sisak-Moslavina County. The old military barracks, that is the military storage facility, is located on the southern slopes of Trgovska Gora at an altitude of about $300 \mathrm{~m}$ above sea level and occupying an area of $0.6 \mathrm{~km} 2$. The location generally meets all the geological criteria, i.e. hydrogeological, hydrological, lithostratigraphic, engineering geological and seismic and seismotectonic criteria for the selection of the location and can therefore be preliminarily considered suitable for the intended purpose.

In accordance with the relevant regulations, a preliminary design of the proposed storage facility was made: a predominantly monolithic reinforced concrete structure with dimensions of $10.0 \mathrm{~m} \times 30.0 \mathrm{~m}$ and a height of $5.9 \mathrm{~m}$, with prefabricated parts: T-section beams and Omnia plates. The main load-bearing structure system is constructed on connected reinforced concrete walls and a frame system. The ceiling construction is made from RC prefabricated, $16 \mathrm{~cm}$ thick Omnia plates with dimensions of $2 \times 5 \mathrm{~m}$. The storage facility is founded on a 40 $\mathrm{cm}$ thick, reinforced concrete base plate. The entire structure design was done in ETABS and SAFE software packages according to the applicable Croatian regulations including the recognized rules of the profession. Given the results of the preliminary design, the chosen structure meets the given load and usability conditions, but in the case of a possible decision to build an actual new storage facility on that particular location, a more detailed analysis would be required.

\section{References}

Državni zavod za radiološku i nuklearnu sigurnost, Republika Hrvatska (State Office for Radiological and Nuclear Safety, Croatia) (2015): Prijedlog nacionalnog programa provedbe Strategije zbrinjavanja radioaktivnog otpada, iskorištenih izvora i istrošenog nuklearnog goriva (Proposal of a National Programme for the implementation of the Strategy for the management of radioactive waste, disused sources and spent nuclear fuel), Zagreb, p. 9-10, Annexes 7- 9. (in Croatian)

EKONERG - Institut za energetiku i zaštitu okoliša d.o.o. (Energy and Environmental Protection Institute) (2016): 
Strateška studija za nacionalni program provedbe strategije zbrinjavanja radioaktivnog otpada, iskorištenih izvora $\mathrm{i}$ istrošenog nuklearnog goriva - netehnički sažetak (Strategic study for the National Programme for the implementation of the Strategy for the management of radioactive waste, disused sources and spent nuclear fuel - a nontechnical summary), Zagreb, 11-32. (in Croatian)

IAEA (2006): IAEA safety standards: Storage of radioactive waste, Vienna

Levanat, I., Lokner, V. (2000): Kako se procjenjuje sigurnost odlagališta nisko i srednje radioaktivnog otpada (How to evaluate the safety of low and intermediate radioactive waste disposal sites), Zagreb, APO (in Croatian)

Milling, A. (2017): Projektiranje skladišta nisko i srednje radioaktivnog otpada (Design of storage facility for low and intermediate radioactive waste), master's thesis, University of Zagreb, Faculty of Mining, Geology and Petroleum Engineering, Zagreb (in Croatian)

Sabor Republike Hrvatske (Croatian Parliament) (1999): Zakon o potvrđivanju Zajedničke konvencije o sigurnosti zbrinjavanja istrošenog goriva i sigurnosti zbrinjavanja radioaktivnog otpada (Act on the Ratification of the Joint Convention on the Safety of Spent Fuel Management and on the Safety of Radioactive Waste Management), Narodne novine - Međunarodni ugovori, br. 3/99 (Official Gazette of the Republic of Croatia-International Agreements, no. 3/99), Zagreb (in Croatian)

Sabor Republike Hrvatske (Croatian Parliament) (2002): Zakon o potvrđivanju Ugovora između Vlade Republike Hrvatske i Vlade Republike Slovenije o uređenju statusnih i drugih pravnih odnosa vezanih uz ulaganje, iskorištavanje i razgradnju Nuklearne elektrane Krško i Zajedničke izjave povodom potpisivanja Ugovora između Vlade Republike Hrvatske i Vlade Republike Slovenije o uređenju statusnih i drugih pravnih odnosa vezanih uz ulaganje, iskorištavanje i razgradnju Nuklearne elektrane Krško (Act on the Ratification of the Agreement between the Government of the Republic of Croatia and the Government of the Republic of Slovenia on Regulation of Status and Other Legal Issues Regarding Investments in Krško NPP, and its Exploitation and Decommissioning and the Joint Statement on the Occasion of Signing of the Agreement between the Government of the Republic of Croatia and the Government of the Republic of Slovenia on Regulation of Status and Other Legal Issues Regarding Investments in Krško NPP, and its Exploitation and Decommissioning), Narodne novine - Međunarodni ugovori, br. 9/02 (Official
Gazette of the Republic of Croatia-International Agreements, no. 9/02), Zagreb, Article 10. (in Croatian)

Sabor Republike Hrvatske (Croatian Parliament) (2013): Zakon o gradnji (Building Act), Narodne novine, br. 153/13 i 20/17 (Official Gazette of the Republic of Croatia, no. 153/13 and 20/17), Zagreb, Article 4. (in Croatian)

Sabor Republike Hrvatske (Croatian Parliament) (2013): Zakon o radiološkoj i nuklearnoj sigurnosti (Act on Radiological and Nuclear Safety), Narodne novine, br. 141/13 i 39/15 (Official Gazette of the Republic of Croatia, no. 141/13 and 39/15), Zagreb, Article 2. (in Croatian)

Schaller, A., Lokner, V. (1998): Obilježja odabranih preferentnih lokacija relevantna za sigurnost odlagališta nisko i srednje radioaktivnog otpada (Characteristics of selected preferential locations relevant to the safety of low and intermediate radioactive waste disposal sites), APO d.o.o., IV. Simpozij HDZZ, Zagreb, 127-133. (in Croatian)

Subašić, D., Škanata, D., Šaler, A. (1992): Pretpostavke zbrinjavanja radioaktivnog otpada u Republici Hrvatskoj ( $\mathrm{Ba}$ sis for radioactive waste management in the Republic of Croatia), Soc. Ekol. Vol 1, No. 2, 203-210. (in Croatian)

Veinović, Ž. (2016): Zbrinjavanje radioaktivnog otpada svjetska praksa i hrvatski izazovi (Disposal of radioactive waste - world practice and Croatian challenges), Kemija u industriji, 65 (7-8), 420-423. (in Croatian)

Vlada RH (Government of the Republic of Croatia) (1992): Zaključak o utvrđivanju kriterija za izbor lokacija za termoelektrane i nuklearne objekte (Conclusion on establishing guidelines for site selection for thermal power plants and nuclear facilities), Narodne novine, br. 78/92 (Official Gazette of the Republic of Croatia, no. 78/92), Zagreb (in Croatian)

Vlada RH (Government of the Republic of Croatia) (2014): Uredba o određivanju građevina, drugih zahvata u prostoru i površina državnog i područnog (regionalnog) značaja (Regulation on the definition of construction works, other projects and surfaces of state and regional significance), Narodne novine, br. 37/14 i 154/14 (Official Gazette of the Republic of Croatia, no. 37/14 and 154/14), Zagreb, Article 2. (in Croatian)

\section{Internet sources}

Državni zavod za radiološku i nuklearnu sigurnost, Republika Hrvatska (State Office for Radiological and Nuclear Safety, Croatia), URL: http://cms.dzrns.hr/opasni_izvori (accessed 31st May 2017) 